\title{
Inhibitory Effects of Total Ginseng Saponin on Catecholamine Secretion from the Perfused Adrenal Medulla of SHRs
}

\author{
Seok-Jeong Jang ${ }^{1}$, Hyo-Jeong $\mathrm{Lim}^{2}$, and Dong-Yoon $\mathrm{Lim}^{3^{*}}$ \\ ${ }^{1}$ Department of Neurosurgery, Chosun University School of Medicine, Gwangju 501-759, Korea \\ ${ }^{2}$ Department of Internal Medicine, Seoul National University College of Medicine, Seoul 110-744, Korea \\ ${ }^{3}$ Department of Pharmacology, Chosun University School of Medicine, Gwangju 501-759, Korea
}

\begin{abstract}
There seems to be some controversy about the effect of total ginseng saponin (TGS) on the secretion of catecholamines (CA) from the adrenal gland. Therefore, the present study aimed to determine whether TGS can affect the CA release in the perfused model of the adrenal medulla isolated from spontaneously hypertensive rats (SHRs). TGS (15-150 $\mu \mathrm{g} / \mathrm{mL})$, perfused into an adrenal vein for $90 \mathrm{~min}$, inhibited the CA secretory responses evoked by acetylcholine (ACh, $5.32 \mathrm{mM}$ ) and high $\mathrm{K}^{+}(56 \mathrm{mM}$, a direct membrane depolarizer) in a dose- and time-dependent fashion. TGS $(50 \mu \mathrm{g} / \mathrm{mL})$ also time-dependently inhibited the CA secretion evoked by 1.1-dimethyl-4 -phenyl piperazinium iodide (DMPP; $100 \mu \mathrm{M}$, a selective neuronal nicotinic receptor agonist) and McN-A-343 (100 $\mu \mathrm{M}$, a selective muscarinic $\mathrm{M}_{1}$ receptor agonist). TGS itself did not affect basal CA secretion (data not shown). Also, in the presence of TGS $(50 \mu \mathrm{g} / \mathrm{mL})$, the secretory responses of CA evoked by veratridine (a selective $\mathrm{Na}^{+}$channel activator $(50 \mu \mathrm{M})$, Bay-K-8644 (an L-type dihydropyridine $\mathrm{Ca}^{2+}$ channel activator, $10 \mu \mathrm{M}$ ), and cyclopiazonic acid (a cytoplasmic $\mathrm{Ca}^{2+}$-ATPase inhibitor, $10 \mu \mathrm{M}$ ) were significantly reduced, respectively. Interestingly, in the simultaneous presence of TGS (50 $\mu \mathrm{g} / \mathrm{mL}$ ) and $\mathrm{N} \omega$-nitro-L-arginine methyl ester hydrochloride [an inhibitor of nitric oxide (NO) synthase, $30 \mu \mathrm{M}$ ], the inhibitory responses of TGS on the CA secretion evoked by ACh, high $\mathrm{K}^{+}$, DMPP, McN-A-343, Bay-K-8644, cyclopiazonic acid, and veratridine were considerably recovered to the extent of the corresponding control secretion compared with the inhibitory effect of TGS-treatment alone. Practically, the level of NO released from adrenal medulla after the treatment of TGS $(150 \mu \mathrm{g} / \mathrm{mL})$ was greatly elevated compared to the corresponding basal released level. Taken together, these results demonstrate that TGS inhibits the CA secretory responses evoked by stimulation of cholinergic (both muscarinic and nicotinic) receptors as well as by direct membrane-depolarization from the isolated perfused adrenal medulla of the SHRs. It seems that this inhibitory effect of TGS is mediated by inhibiting both the influx of $\mathrm{Ca}^{2+}$ and $\mathrm{Na}^{+}$into the adrenomedullary chromaffin cells and also by suppressing the release of $\mathrm{Ca}^{2+}$ from the cytoplasmic calcium store, at least partly through the increased $\mathrm{NO}$ production due to the activation of nitric oxide synthase, which is relevant to neuronal nicotinic receptor blockade, without the enhancement effect on the CA release. Based on these effects, it is also thought that there are some species differences in the adrenomedullary CA secretion between the rabbit and SHR.
\end{abstract}

Keywords: total ginseng saponin, Catecholamine secretion, Adrenal medulla, Nitric oxide production, Nitric oxide synthase

(c) This is an Open Access article distributed under the terms of the Creative Commons Attribution Non-Commercial License (http://creativecommons.org/licenses/by-nc/3.0/) which permits unrestricted non-commercial use, distribution, and reproduction in any medium, provided the original work is properly cited.
Received 25 Dec. 2010, Revised 28 Jan. 2011, Accepted 09 Feb. 2011

This paper was presented at the 33rd Annual Scientific Meeting of the Japanese Society of Hypertension, Fukuoka, Japan, October 15-17, 2010, also at the 10th International Symposium on Ginseng, Seoul, Korea, September 13-16, 2010.

*Corresponding author

E-mail: dylim@chosun.ac.kr

Tel: +82-62-230-6335, Fax: +82-62-227-4693 


\section{INTRODUCTION}

Lim and his coworkers [1-3] have found that all of total ginseng saponin (TGS), panaxadiol and panaxatriol cause the increased secretion of catecholamines (CA) from the isolated perfused rabbit adrenal glands in $\mathrm{a} \mathrm{Ca}^{2+}$ dependent fashion, which are mediated by the activation of cholinergic (both nicotinic and muscarinic) receptors and partly the direct action on the rabbit adrenomedullary chromaffin cells. However, it has been reported that TGS shows the inhibitory effect on the CA release evoked by stimulation of nicotinic receptors in the perfused rat adrenal medulla [4], and also that several ginseng saponins (ginsenosides) from the ginseng root inhibit the CA secretion from bovine adrenal chromaffin cells stimulated by acetylcholine (ACh) [5-8].

Moreover, it has been known that ginsenosides or ginseng extracts cause the hypotensive action [9-13] while they can rather produces the hypertensive action [14-17]. TGS is found to produce the pressor and depressor actions in the anesthetized normotensive rats [18].

Furthermore, ginseng, when given at small dose in spontaneously hypertensive rat (SHR), causes pressor response, but at relatively large dose rather produces dosedependent hypotensive response with decreased plasma renin activity [19-21]. Sokabe and his coworkers [22] have shown that administration of Korean Red ginseng powder for 11 weeks has no effect on blood pressure in normotensive Donryu rats, SHR and renal hypertensive rats, whereas it elevates slightly blood pressure in deoxycorticosterone salt hypertensive rats. Recently, it has also been reported that long-term use of North American ginseng had no effect on 24-hour blood pressure and renal function in hypertensive individuals [23].

In the conscious rats, the releasing effect of nitric oxide (NO) of Korean red ginseng (KRG) may be partly contributed to the hypotensive effect of KRG [11]. It has also been shown that $\mathrm{Rg}_{3}$ relaxes the rat thoracic aorta as a consequence of NO production [24]. Han and his co-workers [25] have found evidence that NO levels in exhaled breath of human volunteers by KRG were increased along with decreased blood pressure and heart rate. In a series of studies, it has been found that ginsenosides reduce blood pressure via increases in production of endothelial nitric oxide [9] and that $\mathrm{Rg}_{3}$ is the most potent ginsenoside that activates endothelial nitric oxide synthase (eNOS) in rat aorta [26]. Although some investigators have demonstrated that $\mathrm{Rg}_{3}$ induces eNOS activation in the vasculature of animal models [9,27], Hien and his co-workers [28] have found that $\mathrm{Rg}_{3}$ activates
eNOS via eNOS phosphorylation in ECV 304 human endothelial cells and increases in eNOS expression.

Several studies have shown that ginsenoside $\mathrm{Rg}_{1}$ can cause endothelial-dependent relaxation in the rat aorta [27] and enhance endogenous NO production in human umbilical vein endothelial cells [29], rat kidney [30] and in porcine coronary arteries [31].

Despite of these many studies, there is still controversy about the functional effects of TGS on the cardiovascular system, especially blood pressure and adrenal CA secretion. Therefore, the aim of the present study was to investigate the ability of TGS on the CA secretion in the perfused model of SHR's adrenal gland, and to establish its mechanism of action.

\section{MATERIALS AND METHODS}

\section{Experimental procedure}

Mature male spontaneously hypertensive rats with reference systolic blood pressure of $178 \pm 6 \mathrm{mmHg}$ (purchased from Damool Science, Seoul, Korea), weighing 200 to 300 grams, were used in the experiment. The animals were housed individually in separate cages, and food (Cheil Animal Chow, Formula M07 ${ }^{\circledR}$, Feedlab, Gyeonggi Province, Korea) and tap water were allowed ad libitum for at least a week to adapt to experimental circumstances. On the day of experiment, a rat was anesthetized with thiopental sodium $(50 \mathrm{mg} / \mathrm{kg})$ intraperitoneally, and tied in supine position on fixing panel.

\section{Isolation of adrenal glands}

The adrenal gland was isolated by the modification of previous method [32]. The abdomen was opened by a midline incision, and the left adrenal gland and surrounding area were exposed by the placement of threehook retractors. The stomach, intestine and portion of the liver were not removed, but pushed over to the right side and covered by saline-soaked gauge pads and urine in bladder was removed in order to obtain enough working space for tying blood vessels and cannulations. A cannula, used for perfusion of the adrenal gland, was inserted into the distal end of the renal vein after all branches of adrenal vein (if any), vena cava and aorta were ligated. Heparin $(400 \mathrm{IU} / \mathrm{mL})$ was injected into vena cava to prevent blood coagulation before ligating vessels and cannulations. A small slit was made into the adrenal cortex just opposite entrance of adrenal vein. Perfusion of the gland was started, making sure that no leakage was present, and the perfusion fluid escaped only from the slit made in adrenal cortex. Then the adrenal gland, along 
with ligated blood vessels and the cannula, was carefully removed from the animal and placed on a platform of a leucite chamber. The chamber was continuously circulated with water heated at $37 \pm 1^{\circ} \mathrm{C}$ (Fig. 1).

\section{Perfusion of adrenal gland}

The adrenal glands were perfused by means of peristaltic pump (ISCO, Lincoln, NE, USA) at a rate of 0.31 $\mathrm{mL} / \mathrm{min}$. The perfusion was carried out with Krebsbicarbonate solution of following composition (mM): $\mathrm{NaCl}, 118.4$; potassium chloride $(\mathrm{KCl}), 4.7 ; \mathrm{CaCl}_{2}, 2.5$; $\mathrm{MgCl}_{2}, 1.18 ; \mathrm{NaHCO}_{3}, 25 ; \mathrm{KH}_{2} \mathrm{PO}_{4}, 1.2$; glucose, 11.7. The solution was constantly bubbled with $95 \% \mathrm{O}_{2}+5 \%$ $\mathrm{CO}_{2}$ and the final $\mathrm{pH}$ of the solution was maintained at 7.4 to 7.5. The solution contained disodium EDTA $(10 \mu \mathrm{g} /$ $\mathrm{mL})$ and ascorbic acid $(100 \mu \mathrm{g} / \mathrm{mL})$ to prevent oxidation of catecholamines.

\section{Drug administration}

The perfusions of 1.1-dimethyl-4 -phenyl piperazinium iodide (DMPP, $100 \mu \mathrm{M}$ ) for $2 \mathrm{~min}$ and/or a single injection of ACh $(5.32 \mathrm{mM})$ and $\mathrm{KCl}(56 \mathrm{mM})$ in a volume of $0.05 \mathrm{~mL}$ were made into perfusion stream via a three-way stopcock, respectively. 3-(m-chlorophenyl-carbamoyl-oxy)-2-butynyl- trimethyl ammonium chloride (McN-A-343, $100 \mu \mathrm{M})$, veratridine $(100 \mu \mathrm{M})$, methyl-1, 4-dihydro-2,6-dimethyl- 3-nitro-4-(2-trifluoromethyl-phenyl)-pyridine-5-carboxylate (Bay-K-8644, 10 $\mu \mathrm{M})$ and cyclopiazonic acid $(10 \mu \mathrm{M})$ were also perfused for $4 \mathrm{~min}$, respectively.

In the preliminary experiments, it was found that upon administration of the above drugs, secretory responses to $\mathrm{ACh}, \mathrm{KCl}, \mathrm{McN}-\mathrm{A}-343$, Bay-K-8644 and cyclopiazonic acid returned to preinjection level in about $4 \mathrm{~min}$, but the responses to DMPP in $8 \mathrm{~min}$.

\section{Collection of perfusate}

As a rule, prior to stimulation with various secretagogues, the perfusate was collected for 4 min to determine the spontaneous secretion of CA (background sample). Immediately after the collection of the background sample, collection of the perfusates was continued in another tube as soon as the perfusion medium containing the stimulatory agent reached the adrenal gland. Stimulated sample's perfusate was collected for 4 to $8 \mathrm{~min}$. The amounts secreted in the background sample have been subtracted from that secreted from the stimulated sample to obtain the net secretion value of $\mathrm{CA}$, which is shown in all of the figures.

To study the effect of TGS on the spontaneous and evoked secretion, the adrenal gland was perfused with normal Krebs solution for $90 \mathrm{~min}$, and then the perfusate was collected for a certain period (background sample). Then the medium was changed to the one containing the stimulating agent or along with TGS, and the perfusates were collected for the same period as that for the background sample. The adrenal gland's perfusate was collected in chilled tubes.

\section{Measurement of catecholamines}

The content of CA (all of epinephrine, norepinephrine and dopamine) in perfusate was measured directly by the fluorometric method of Anton and Sayre [33] without the intermediate purification alumina for the reasons described earlier [32] using fluorospectrophotometer (Kontron Co., Milano, Italy).

A volume of $0.2 \mathrm{~mL}$ of the perfusate was used for the reaction. The CA content in the perfusate of stimulated glands by secretagogues used in the present work was high enough to obtain readings several folds greater than the reading of control samples (unstimulated). The sample blanks were also lowest for perfusates of stimulated and non-stimulated samples. The CA content in the perfusate was expressed in terms of norepinephrine (base) equivalents.

\section{Measurement of nitric oxide release}

NO release was measured using a NO-selective microelectrode (ami700; Innovative Instruments Inc., Tampa, FL, USA) and an amplifier (inNo meter, Innovative Instruments Inc.). Adrenomedullary NO production was quantified as the integrated signal detected by the microelectrode after perfusion of TGS into adrenal medulla of SHRs, as previously described [34]. The electrode was calibrated by producing standardized concentrations of $\mathrm{NO}$ in $0.5 \%$ (wt/vol) $\mathrm{KI}$ in $0.1 \mathrm{~mol} / \mathrm{L} \mathrm{H}_{2} \mathrm{SO}_{4}$ from $\mathrm{NaNO}_{2}$ standards. NO release was quantitated as the current detected at the electrode after loading TGS into adrenal medulla. NO release was calculated as picomoles.

\section{Statistical analysis}

The statistical difference between the control and the pretreated groups was determined by the Student's t-test and ANOVA test. A $p$-value of less than 0.05 was considered to represent statistically significant changes unless specifically noted in the text. Values given in the text refer to means and the standard errors of the mean. The statistical analysis of the experimental results was made by computer program described by Tallarida and Murray [35]. 
A

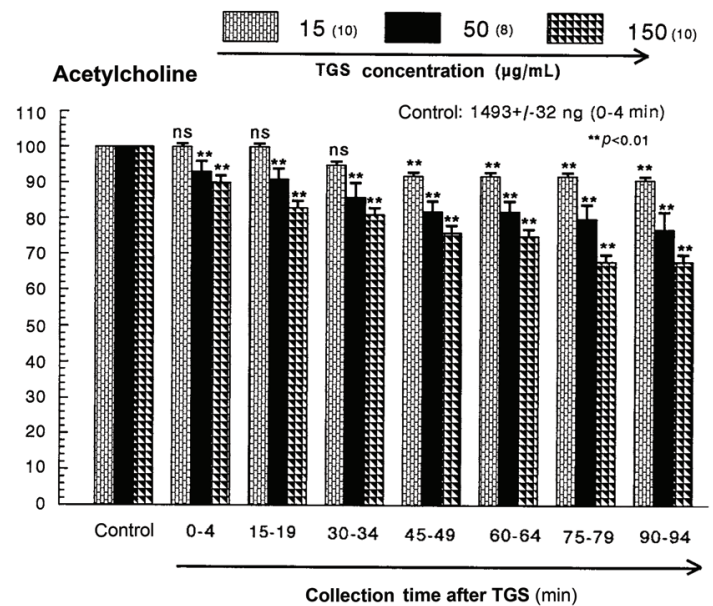

B

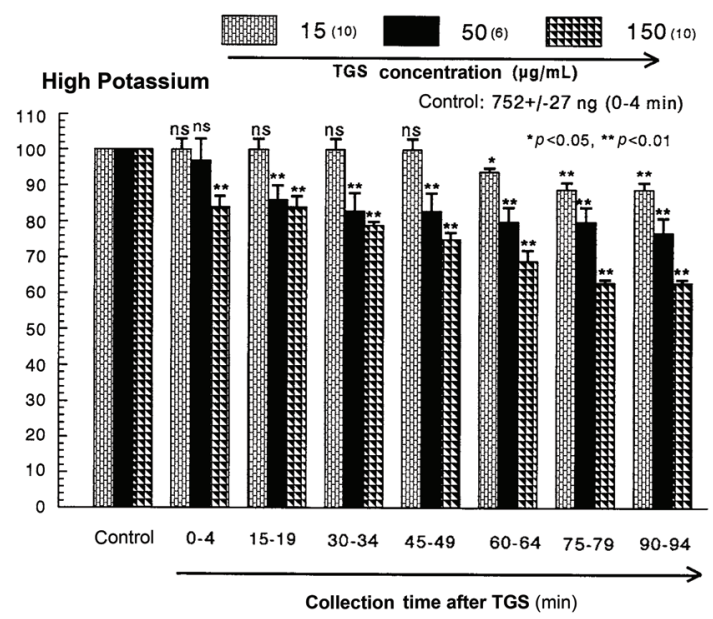

Fig. 1. Dose-dependent effects of saponin total ginseng (TGS) on the secretory responses of CA evoked by acetylcholine $(A)$ and high potassium (B) from the perfused rat adrenal medulla. The CA secretion by a single injection of $\mathrm{ACh}(5.32 \mathrm{mM})$ and $\mathrm{K}^{+}(56 \mathrm{mM})$ in a volume of $0.05 \mathrm{~mL}$ was evoked at 15 min intervals during loading with 15,50 and $150 \mu \mathrm{g} / \mathrm{mL}$ of TGS for $90 \mathrm{~min}$ as indicated by the arrow marks, respectively. The numbers in parentheses indicate the number of rat adrenal glands. Vertical bars on the columns represent the standard error of the mean \pm SEM. Ordinate: the amounts of CA secreted from the adrenal gland (\% of control). Abscissa: collection time of perfusate $(\mathrm{min})$. Statistical difference was obtained by comparing the corresponding control with each concentration-treated group of TGS. ACh- and high K+-induced perfusates were collected for 4 minutes, respectively. ns, not statistically significant. ${ }^{*} p<0.05$, ${ }^{* *} p<0.01$.

\section{Drugs and their sources}

The following drugs were used: 1.1-dimethyl-4 -phenyl piperazinium iodide (DMPP), acetylcholine chloride, norepinephrine bitartrate, potassium chloride $(\mathrm{KCl}), \mathrm{N}^{\omega}$ nitro-L-arginine methyl ester hydrochloride (L-NAME), methyl-1,4-dihydro-2,6-dimethyl-3-nitro-4-(2-trifluoromethyl-phenyl)-pyridine-5-carboxylate (BAY-K-8644), cyclopiazonic acid, potassium nitrate (Sigma Chemical Co., St Louis, MO, USA), veratridine and 3-(m-cholro- phenyl-carbamoyl-oxy)-2-butynyl-trimethyl ammonium chloride [McN-A-343] (RBI, Natick, MA, USA). total ginseng saponin were a gift from late Dr. Young-Ho Kim (Professor of Sejong University, Seoul, Korea). Drugs were dissolved in distilled water (stock) and added to the normal Krebs solution as required except Bay-K-8644, which was dissolved in $99.5 \%$ ethanol and diluted appropriately with Krebs-bicarbonate solution (final concentration of alcohol was less than $0.1 \%$ ). Concentrations of all drugs except TGS used were expressed in terms of molar base.

\section{RESULTS}

\section{Effects of TGS on the CA secretion evoked by ACh, high $\mathrm{K}^{+}$, DMPP and McN-A-343 from the perfused adrenal glands of the SHRs}

After the perfusion with oxygenated Krebs-bicarbonate solution for $1 \mathrm{~h}$, basal CA release from the isolated perfused rat adrenal glands amounted to $21 \pm 2 \mathrm{ng}$ for $2 \min (n=10)$. Since, it has been found that ginseng saponins cause the increased CA secretion from the isolated perfused rabbit adrenal glands [1-3] while rather inhibited the CA secretion in rat adrenal gland [4] and in bovine adrenal chromaffin cells $[5,6,8,36]$, it was attempted initially to examine the effects of TGS itself on CA secretion from the perfused model of the adrenal glands of the SHRs. However, in the present study, TGS $(15-150 \mu \mathrm{g} / \mathrm{mL})$ itself did not produce any effect on basal CA output from the perfused rat adrenal glands (data not shown). Therefore, it was decided to investigate the effects of TGS on cholinergic receptor stimulation- as well as membrane depolarization-evoked CA secretion. Secretagogues were given at 15 to 20 min-intervals. TGS was present for 90 minutes after the establishment of the control release.

When ACh $(5.32 \mathrm{mM})$ in a volume of $0.05 \mathrm{~mL}$ was injected into the perfusion stream, the amount of CA secreted was $1493 \pm 32 \mathrm{ng}$ for $4 \mathrm{~min}$. However, the pretreatment with TGS in the range of $15-150 \mu \mathrm{g} / \mathrm{mL}$ for $90 \mathrm{~min}$ relatively concentration- and time-dependently inhibited ACh-stimulated CA secretion. As shown in Fig. 1A, in the presence of TGS, the CA releasing responses were inhibited to $68 \%$ of the corresponding control release $(100 \%)$. Also, it has been found that depolarizing agent like $\mathrm{KCl}$ stimulates markedly CA secretion $(752 \pm 27 \mathrm{ng}$ for 0-4 min). High $\mathrm{K}^{+}(5.6 \mathrm{mM})$-stimulated CA secretion after the pretreatment with $15 \mu \mathrm{g} / \mathrm{mL}$ TGS was not affected for the first $45 \mathrm{~min}$ period as compared with its corresponding control secretion (Fig. 1B). However, 
A DMPP (8)

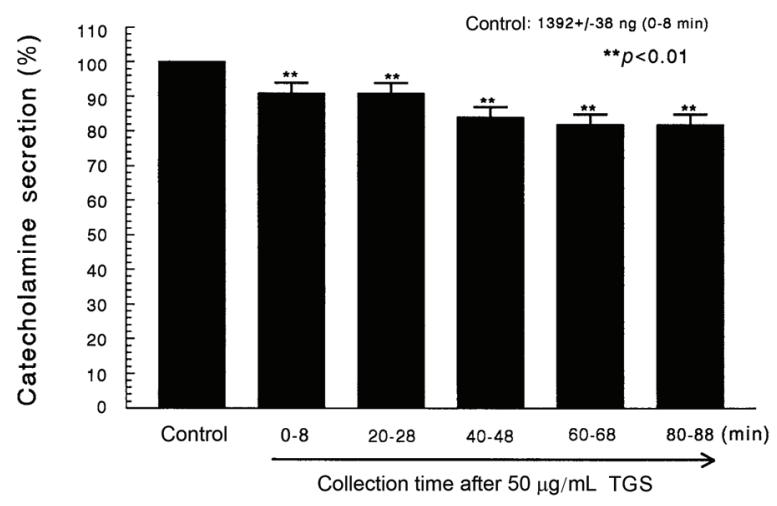

B McN-A-343 (6)

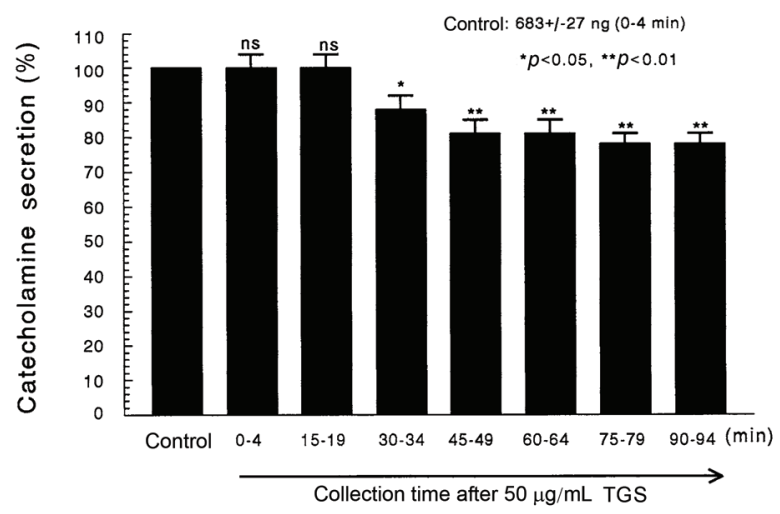

Fig. 2. Time-course effects of TGS on the CA secretory responses evoked by DMPP (A) and McN-A-343 (B) from the perfused rat adrenal medulla. The CA secretion by perfusion of DMPP $(100 \mu \mathrm{M})$ for $2 \mathrm{~min}$ and McN-A-343 $(100 \mu \mathrm{M})$ for $4 \mathrm{~min}$ was induced at 20 and $15 \mathrm{~min}$ intervals during loading with $50 \mu \mathrm{g} / \mathrm{mL}$ of TGS for $90 \mathrm{~min}$, respectively. DMPP- and McN-A-343-induced perfusates were collected for 8 and 4 minutes, respectively. Other legends are the same as in Fig. 1. ns, not statistically significant. ${ }^{*} p<0.05,{ }^{* *} p<0.01$.

following the pretreatment with higher concentrations of TGS $(50-150 \mu \mathrm{g} / \mathrm{mL})$, high $\mathrm{K}^{+}(56 \mathrm{mM})$-stimulated CA secretion was maximally inhibited to $63 \%$ of the control after $75 \mathrm{~min}$ period, although it was not initially affected at $50 \mu \mathrm{g} / \mathrm{mL}$ of TGS. DMPP $(100 \mu \mathrm{M})$, which is a selective nicotinic receptor agonist in autonomic sympathetic ganglia, evoked a sharp and rapid increase in CA secretion (1392 $\pm 38 \mathrm{ng}$ for 0-8 min). However, as shown in Fig. 2A, DMPP-stimulated CA secretion after the pretreatment with TGS $(50 \mu \mathrm{g} / \mathrm{mL})$ was greatly reduced to $80 \%$ of the control release. As shown in Fig. 2B, McN-A-343 $(10 \mu \mathrm{M})$, which is a selective muscarinic $\mathrm{M}_{1}$-agonist [37], perfused into an adrenal gland for 4 min caused an increased CA secretion $(683 \pm 27 \mathrm{ng}$ for 0-4 min). However, McN-A-343-stimulated CA secre-

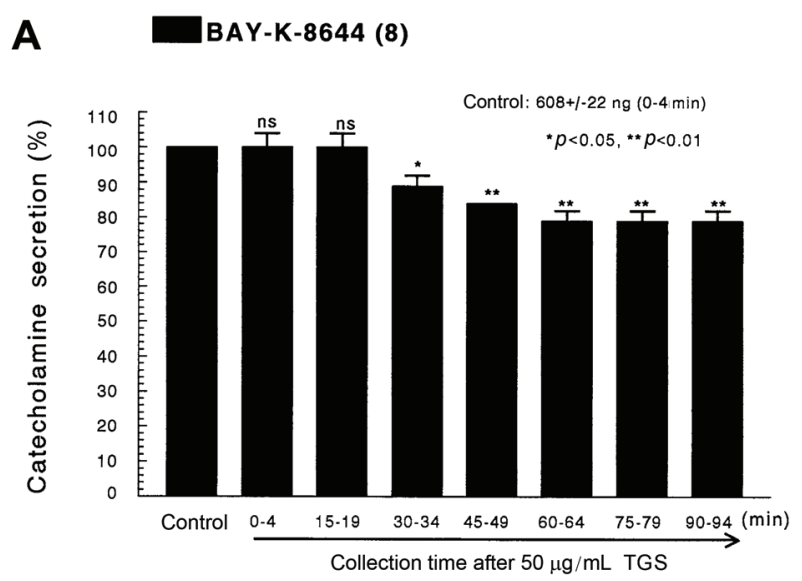

B

Cyclopiazonic acid (8)

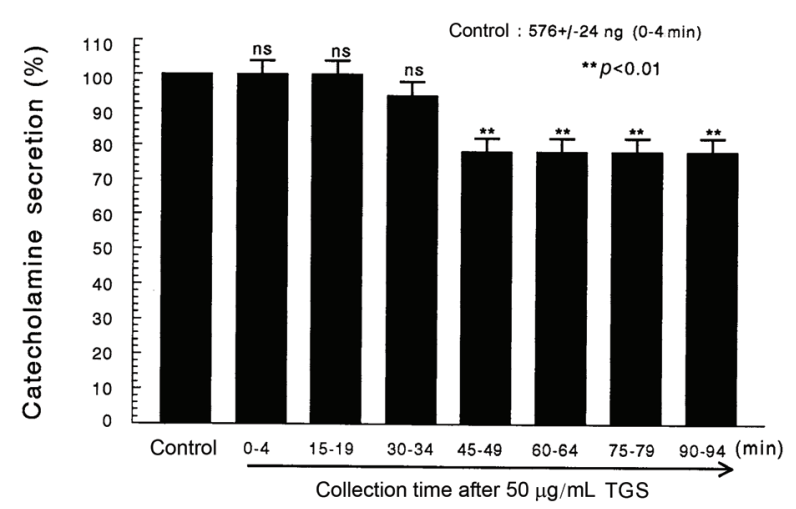

Fig. 3. Time-course effects of TGS on the CA secretion evoked by Bay-K-8644 (A) and cyclopiazonic acid (B) from the perfused rat adrenal medulla. Bay-K-8644 $(10 \mu \mathrm{M})$ and cyclopiazonic acid $(10 \mu \mathrm{M})$ were perfused into an adrenal vein for $4 \mathrm{~min}$ at $15 \mathrm{~min}$ intervals during loading with TGS $(50 \mu \mathrm{g} / \mathrm{mL})$ for $90 \mathrm{~min}$. Other legends are the same as in Fig. 1. ns, not statistically significant. ${ }^{*} p<0.05,{ }^{* *} p<0.01$.

tion in the presence of TGS $(50 \mu \mathrm{g} / \mathrm{mL})$ was markedly depressed to $78 \%$ of the corresponding control secretion $(100 \%)$.

\section{Effects of TGS on the CA secretion evoked by Bay- $\mathrm{K}-8644$, cyclopiazonic acid and veratridine from the perfused adrenal glands of the SHRs}

Since Bay-K-8644 is known to be a calcium channel activator, which enhances basal $\mathrm{Ca}^{2+}$ uptake [38] and CA release [39], it was of interest to determine the effects of TGS on Bay-K-8644-stimulated CA secretion from the isolated perfused rat adrenal glands. Bay-K-8644 (10 $\mu \mathrm{M}$ )-stimulated CA secretion in the presence of TGS (50 $\mu \mathrm{g} / \mathrm{mL}$ ) was reduced to $79 \%$ of the control except for the early $15 \mathrm{~min}$ period as compared to the corresponding control release (608 $\pm 22 \mathrm{ng}$ for $0-4 \mathrm{~min}$ ) from 8 adrenal 


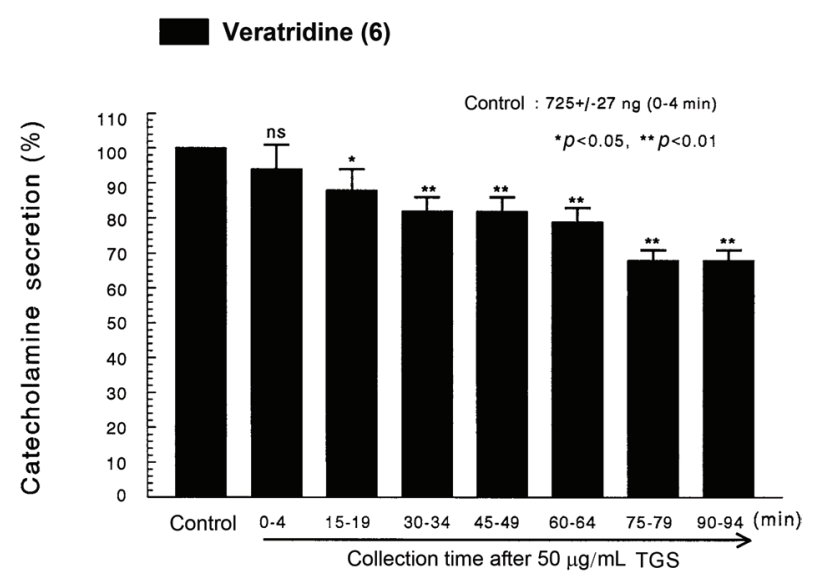

Fig. 4. Time-course effects of TGS on veratridine-evoked CA secretion from the perfused rat adrenal medulla. Veratridine $(50 \mu \mathrm{M})$ was perfused into an adrenal vein for 4 min at 15 min intervals during loading with TGS $(50 \mu \mathrm{g} / \mathrm{mL})$ for $90 \mathrm{~min}$. Other legends are the same as in Fig. 1. ns, not statistically significant. ${ }^{*} p<0.05,{ }^{* *} p<0.01$.

glands of SHRs, as shown in Fig. 3A.

Cyclopiazonic acid, a mycotoxin from Aspergillus and Penicillium, has been described as a highly selective inhibitor of $\mathrm{Ca}^{2+}$-ATPase in skeletal muscle sarcoplasmic reticulum $[40,41]$. The inhibitory action of TGS on cyclopiazonic acid-evoked CA secretory response was observed as shown in Fig. 3B. However, in the presence of TGS $(50 \mu \mathrm{g} / \mathrm{mL})$ in 8 adrenal glands of SHRs, cyclopiazonic acid $\left(10^{-5} \mathrm{M}\right)$-evoked CA secretion was also inhibited to $78 \%$ of the control response $(576 \pm 24 \mathrm{ng}$ for 0-4 min).

It has been known that veratridine-induced $\mathrm{Na}^{+}$influx mediated through voltage-dependent $\mathrm{Na}^{+}$channels increased $\mathrm{Ca}^{2+}$ influx via activation of voltage-dependent $\mathrm{Ca}^{2+}$ channels and produced the exocytotic CA secretion in cultured bovine adrenal medullary cells [42]. As shown in Fig. 4, veratridine $\left(5 \times 10^{-5} \mathrm{M}\right)$ sharply produced CA secretion ( $725 \pm 27 \mathrm{ng}$ for $0-4 \mathrm{~min})$. TGS $(50 \mu \mathrm{g} / \mathrm{mL})$ also attenuated veratridine-induced CA secretion to $68 \%$ of the corresponding control release in a time-dependent manner.

\section{Effects of TGS plus L-NAME on the CA release evoked by ACh, high $\mathrm{K}^{+}$, DMPP and McN-A-343 from the perfused adrenal glands of the SHRs}

It has also been found that, in this study, TGS inhibited the CA secretory response evoked by cholinergic stimulation in the perfused adrenal glands of SHRs. Therefore, to study the relationship between NO and TGSinduced inhibitory effects on the CA release from the adrenal glands of SHRs, the effect of L-NAME on TGSinduced inhibitory responses of CA secretion evoked by cholinergic receptor-stimulation as well as membrane
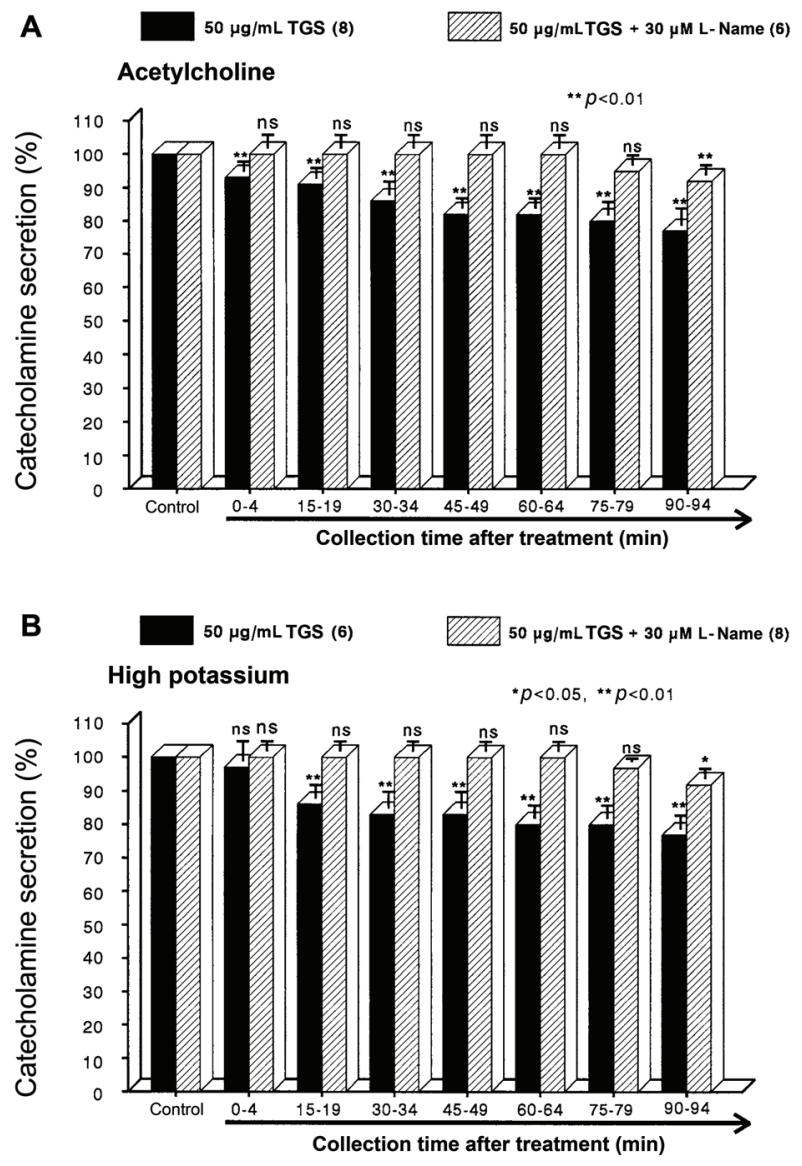

Fig. 5. Effects of TGS plus L-NAME on the CA secretory responses evoked by acetylcholine (A) and high potassium (B) from the perfused rat adrenal medulla. The CA secretion by a single injection of ACh $(5.32 \mathrm{mM})$ and $\mathrm{K}^{+}(56 \mathrm{mM})$ in a volume of $0.05 \mathrm{~mL}$ was evoked at $15 \mathrm{~min}$ intervals during simultaneous loading with TGS $(50 \mu \mathrm{g} / \mathrm{mL})$ plus L-NAME $(30 \mu \mathrm{M})$ for $90 \mathrm{~min}$. Statistical difference was obtained by comparing the corresponding control with TGS-treated group or group treated with TGS+L-NAME. Other legends are the same as in Fig. 1. ns, not statistically significant. ${ }^{*} p<0.05,{ }^{* *} p<0.01$.

depolarization was examined. In the present study, in the simultaneous presence of TGS $(50 \mu \mathrm{g} / \mathrm{mL})$ and L-NAME $(30 \mu \mathrm{M})$ for $90 \mathrm{~min}$ from 6 adrenal glands of SHRs, ACh (5.32 $\mathrm{mM}$ )-evoked CA release was initially not affected at first $4 \mathrm{~min}$, but later rather recovered to $92 \%$ of the corresponding control release at the period of 90-94 min compared to that of TGS ( $50 \mu \mathrm{g} / \mathrm{mL})$-treated group only, as illustrated in Fig. 5A. High $\mathrm{K}^{+}(56 \mathrm{mM})$-evoked CA release in the presence of TGS $(50 \mu \mathrm{g} / \mathrm{mL})$ and L-NAME $(30 \mu \mathrm{M})$ for $90 \mathrm{~min}$ was also not changed for 0-64 min, and then recovered to $92 \%$ of the corresponding control release at the last period of 90 to $94 \mathrm{~min}$ period in comparison to that of TGS $(50 \mu \mathrm{g} / \mathrm{mL})$-treated group only from 8 glands (Fig. 5B). As shown in Fig. 6A, the simultaneous perfusion of TGS and L-NAME for 90 min no 

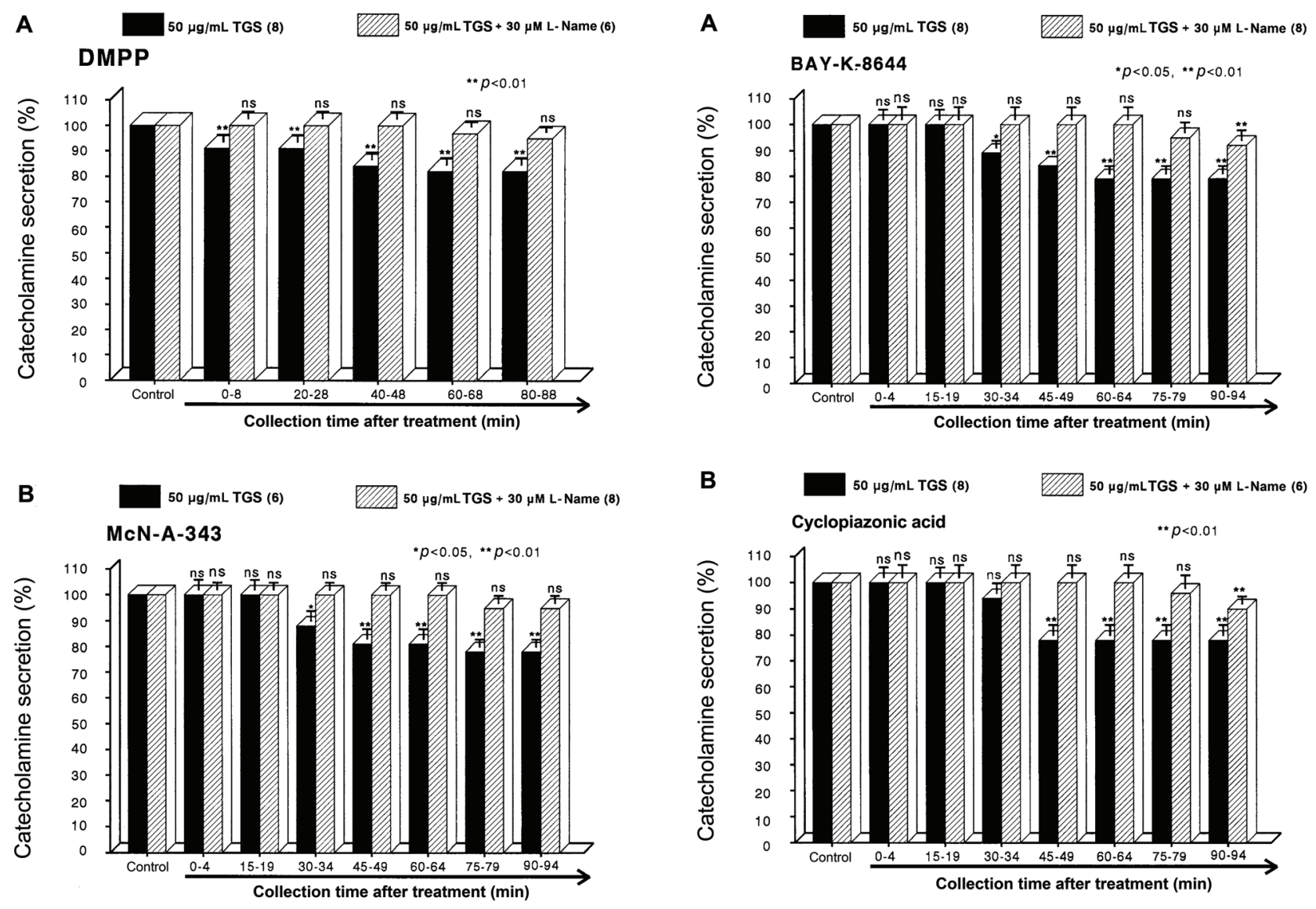

Fig. 6. Effects of TGS plus L-NAME on the CA secretory responses evoked by DMPP (A) and McN-A-343 (B) from the perfused rat adrenal medulla. The CA secretion by perfusion of DPPP $(100 \mu \mathrm{M})$ for 2 min and McN-A-343 (100 $\mu \mathrm{M})$ for 4 min was induced at 20 and 15 min intervals after preloading with TGS $(50 \mu \mathrm{g} / \mathrm{mL})$ plus L-NAME (30 $\mu \mathrm{M}$ ) for $90 \mathrm{~min}$, respectively. Other legends are the same as in Fig. 1 and 5 . ns, not statistically significant. ${ }^{*} p<0.05,{ }^{* *} p<0.01$.

longer inhibited DMPP-evoked CA release for the period of 0-68 min from 6 adrenal glands while later rather recovered to $95 \%$ of the control release at the period of $80-88$ min. Moreover, in the simultaneous presence of TGS and L-NAME for $90 \mathrm{~min}, \mathrm{McN}-\mathrm{A}-343$-evoked CA secretory responses was also time-dependently recovered to $95 \%$ of the control secretion compared to that of TGS $(50 \mu \mathrm{g} / \mathrm{mL})$ treated group only from 8 glands as shown in Fig. 6B, although they were not affected at period of 0-64 min.

\section{Effects of TGS plus L-NAME on the CA release evoked by BAY-K-8644, cyclopiazonic acid and ve- ratridine from the perfused adrenal glands of the SHRs}

As shown in Fig. 7A, the simultaneous perfusion of TGS $(50 \mu \mathrm{g} / \mathrm{mL})$ and L-NAME $(30 \mu \mathrm{M})$ for $90 \mathrm{~min}$ no longer inhibited the CA release evoked by Bay-K-8644

Fig. 7. Effects of TGS plus L-NAME on the CA secretory responses evoked by Bay-K-8644 (A) and cyclopiazonic acid (B) from the perfused rat adrenal medulla. Bay-K-8644 $(10 \mu \mathrm{M})$ and cyclopiazonic acid $(10 \mu \mathrm{M})$ were perfused into an adrenal vein for $4 \mathrm{~min}$ at $15 \mathrm{~min}$ intervals during simultaneous loading with TGS $(50 \mu \mathrm{g} / \mathrm{mL})$ plus LNAME $(30 \mu \mathrm{M})$ for $90 \mathrm{~min}$. Other legends are the same as in Fig. 1 and 5 . ns, not statistically significant. ${ }^{*} p<0.05,{ }^{* *} p<0.01$.

for the period of 0-64 min from 8 glands, and then also recovered to $92 \%$ of the control release at the last period of 90-94 min in comparison to that of TGS (50 $\mu \mathrm{g} /$ $\mathrm{mL}$ )-treated group only. As shown in Fig. 7B, in the presence of TGS $(50 \mu \mathrm{g} / \mathrm{mL})$ and L-NAME $(30 \mu \mathrm{M})$ for $90 \mathrm{~min}$ in 6 rat adrenal glands, cyclopiazonic acid $\left(10^{-}\right.$ ${ }^{5} \mathrm{M}$ )-evoked CA secretion was recovered to $90 \%$ of the control response $(100 \%)$ at the period of 90 to $94 \mathrm{~min}$ in comparison to that of TGS $(60 \mu \mathrm{g} / \mathrm{mL})$-treated group only. Also, the simultaneous perfusion of TGS $(50 \mu \mathrm{g} /$ $\mathrm{mL})$ and L-NAME $(30 \mu \mathrm{M})$ for $90 \mathrm{~min}$ no longer reduced the veratridine-evoked CA release for the period of 0 to 64 min from 8 glands, and then finally recovered to $86 \%$ of the control release at the last period of 90 to $94 \mathrm{~min}$ in comparison to that of TGS $(50 \mu \mathrm{g} / \mathrm{mL})$-treated group only (Fig. 8). 


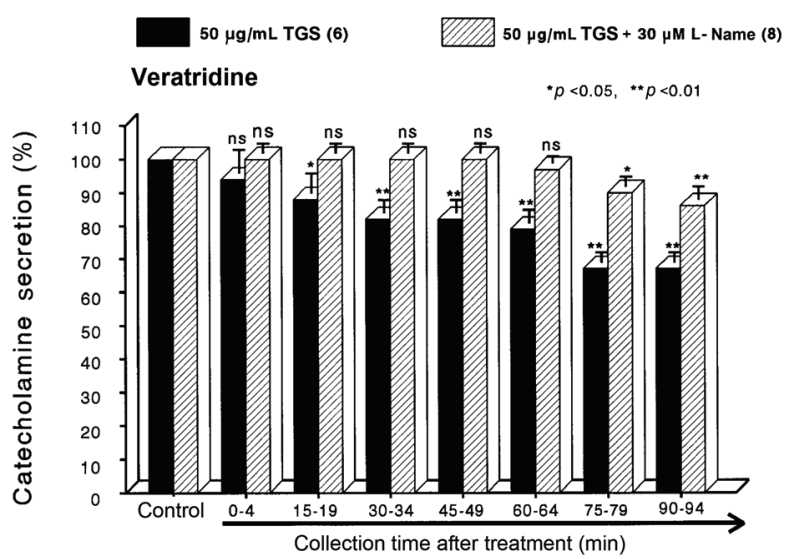

Fig. 8. Effects of TGS plus L-NAME on veratridine-evoked CA secretory responses from the perfused rat adrenal medulla. Veratridine $(50 \mu \mathrm{M})$ was perfused into an adrenal vein for $4 \mathrm{~min}$ at $15 \mathrm{~min}$ intervals during simultaneous loading with TGS $(50 \mu \mathrm{g} / \mathrm{mL})$ plus L-NAME $(30 \mu \mathrm{M})$ for $90 \mathrm{~min}$. Other legends are the same as in Fig. 1 and 5. ns, not statistically significant. ${ }^{*} p<0.05,{ }^{* *} p<0.01$.

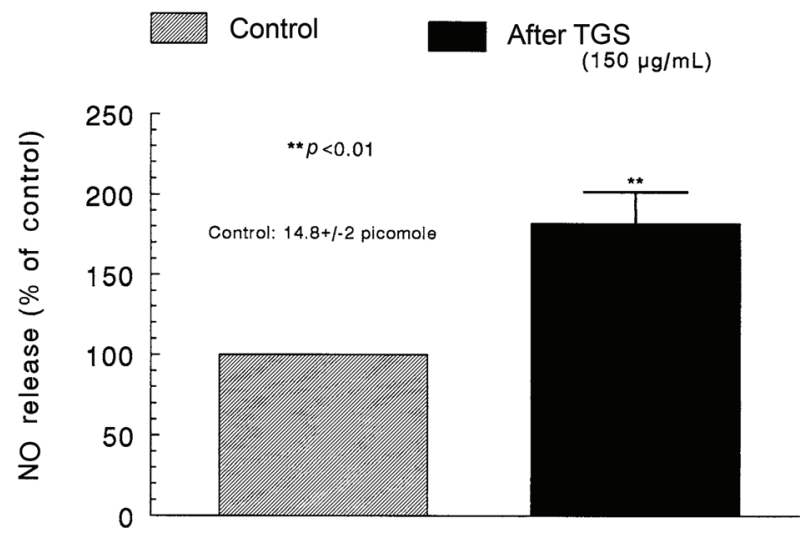

Fig. 9. Effects of TGS on nitric oxide (NO) production in the perfused rat adrenal medulla. Perfusate sample was taken for $8 \mathrm{~min}$ after loading the perfusion of TGS $(150 \mu \mathrm{g} / \mathrm{mL})$ at a rate of $0.31 \mathrm{~mL} /$ min. Ordinate: the amounts of NO released from the adrenal medulla (\% of control). Abscissa: treatment (before and after TGS). Statistical difference was made by comparing the control with TGS-treated group. ${ }^{* *} p<0.01$.

\section{Effect of TGS on the level of nitric oxide released from the perfused adrenal medulla of the SHRs}

As shown in Figs. 5-8, the inhibitory effects of TGS on cholinergic stimulation- and direct membrane depolarization-evoked CA secretory responses were significantly reduced in the presence of L-NAME. Therefore, it was decided directly to determine the level of NO released from adrenal medulla of SHRs after the treatment of TGS. Moreover, it has been found that ginsenosides reduce blood pressure via increases in production of endothelial nitric oxide [9] and that ginsenoside $\mathrm{Rg}_{3}$ is the most potent ginsenoside that activates eNOS in rat aorta
[26]. Although some investigators have demonstrated that $\mathrm{Rg}_{3}$ induces eNOS activation in the vasculature of animal models [9,27].

In 10 adrenal glands, the basal amount of NO released from medulla prior to administration of TGS was $14.8 \pm 2$ picomoles. However, 8 min after loading with TGS (150 $\mu \mathrm{g} / \mathrm{mL}$ ) it was greatly elevated to $27.0 \pm 3 \rho \mathrm{M}$, which was $182 \%$ of the basal release, as shown in Fig. 9.

\section{DISCUSSION}

The present experimental results have suggested that TGS inhibits the CA secretory responses from the isolated perfused adrenal gland of the SHRs evoked by stimulation of cholinergic (both muscarinic and nicotinic) receptors as well as by direct membrane-depolarization. It seems that this inhibitory effect of TGS is exerted by inhibiting influx of both $\mathrm{Na}^{+}$and $\mathrm{Ca}^{2+}$ ions into the adrenomedullary chromaffin cells of the SHRs and also by suppression of $\mathrm{Ca}^{2+}$ release from the cytoplasmic calcium store at least partly through the activation of NO production, which is relevant to the blockade of neuronal nicotinic receptors.

In the present study, in the simultaneous presence of TGS and L-NAME (NO synthase inhibitor), the CA secretory responses evoked by $\mathrm{ACh}$, high $\mathrm{K}^{+}$, DMPP, McN-A-343, Bay-K-8644, cyclopiazonic acid, and veratridine were considerably recovered to the extent of the corresponding control secretion compared to those of TGS treatment alone. This result is well consistent with the report that, in a series of studies, ginsenosides reduce blood pressure via increases in production of endothelial nitric oxide [9] and that ginsenoside $\mathrm{Rg}_{3}$ is the most potent ginsenoside that activates eNOS in rat aorta [26]. Although several investigators have demonstrated that $\mathrm{Rg}_{3}$ induces eNOS activation in the vasculature of animal models [9,27], Hien and his co-workers [28] have found that $\mathrm{Rg}_{3}$ activates eNOS via eNOS phosphorylation in ECV 304 human endothelial cells and increases in eNOS expression. Moreover, in this study, following treatment of TGS into adrenal medulla of SHRs, NO production was greatly elevated as shown in Fig. 9. Taking into account these findings, in the present study, it is likely that TGS inhibits the CA secretory response evoked by various secretagogues through increasing NO production in adrenal chromaffin cells since TGS-induced inhibitory responses of CA secretion were significantly reduced in the presence of L-NAME, an inhibitor of NO synthase, and TGS practically enhanced NO release from adrenal medulla of SHRs. 
In support of this idea, several studies have shown that ginsenoside $\mathrm{Rg}_{1}$ can cause endothelial-dependent relaxation in the rat aorta [27] and enhance endogenous NO production in human umbilical vein endothelial cells [29], rat kidney [30] and in porcine coronary arteries [31]. Nitric oxide has been implicated in many actions of ginseng [43], including the ability of ginseng and ginsenosides to relax rabbit pulmonary [44] and monkey cerebral arteries [45], decrease neuronal ischemia [46], and inhibit stressinduced glucocorticoid secretion in mice [47].

Some studies have demonstrated antioxidant actions of the crude extract of the Panax ginseng (GE), and those related to NO synthesis and release [43]. Chen and Lee [48] reported that GE potentiated the relaxant response to electrical nerve stimulation of isolated rabbit corpus cavernosum. Such a neurogenic response in a variety of vasculature, including the cerebral artery [49], and corpus cavernosum [50] is mediated by NO liberated from autonomic efferent nerves that belongs to the parasympathetic nervous system and is called 'nitroxidergic' [51]. This inhibitory nerve is recognized to play important roles in the regulation of cerebrovascular resistance and cerebral blood flow [52] and intracavernous pressure/ penile erection [53]. Based on these reports, the results of the present study indicate that TGS can inhibit the CA release evoked by cholinergic stimulation and membrane depolarization from the adrenal medulla of SHRs at least by the increased NO production due to activation of neuronal nitric oxide synthase, since this inhibitory effect of TGS on the CA secretory responses was significantly attenuated in the presence of L-NAME, an inhibitor of nitric oxide synthase, and TGS actually enhanced NO release from the perfused adrenal medulla.

In support of this idea, generally, NO is produced enzymatically from the terminal guanidino nitrogen of Larginine by the action of NOS $[54,55]$. There are at least three isoforms of NOS: neuronal NOS (nNOS), eNOS, and inducible NOS. The adrenal medulla possesses characteristic postganglionic sympathetic neurons, and the presence of nNOS has been demonstrated [56-59]. In vitro studies using NOS inhibitors and NO donors were performed to examine the role of NO in modulating CA secretion from the adrenal medulla but the results remain controversial. In the present work, in presence of L-NAME, the inhibitory responses of TGS on the CA secretion were recovered to the considerable extent of the control secretion compared with the inhibitory effects of TGS-treatment alone. This result indicates that TGS can inhibit the CA release at least partly through the activation of nNOS in the adrenal medulla of SHRs. In the sup- port of this finding, it has been reported that the NOS inhibitor, L-NAME enhances $\mathrm{K}^{+}$-stimulated CA secretion in cultured bovine chromaffin cells [60] and that sodium nitroprusside (SNP) inhibits ACh-induced CA secretion in bovine chromaffin cells [61]. These studies suggest that NO may play an inhibitory role in the control of the CA secretion. Moreover, the presence of endothelial cells has been reported to inhibit the $\mathrm{K}^{+}$-induced or the nicotinic receptor agonist DMPP-induced CA secretion in cultured bovine chromaffin cells [60], suggesting that not merely nNOS but also eNOS may play roles in modulating adrenal CA secretion. In view of the results so far reported, the present studies strongly suggest that TGS possesses the ability partly to activate nNOS in the adrenomedullary chromaffin cells of SHRs, resulting in enhancement of $\mathrm{NO}$ as well as inhibition of the CA release, in addition to the direct inhibitory effects on the CA secretion. In supporting this finding, among the ginsenosides of the protopanaxatriol and protopanaxadiol groups, ginsenoside $\mathrm{Rg}_{3}$ is the most potent vasodilator. Previously, it was shown that $\operatorname{Rg}_{3}$ inhibited calcium-induced vascular contraction [26] as well as phenylephrine-induced vasocontraction as a consequence of NO production [24]. Recently, it is known that ginsenoside Re also releases NO via a membrane sex steroid receptors, resulting in activation of large-conductance $\mathrm{Ca}^{2+}$-activated $\mathrm{K}^{+}$channels $(\mathrm{K} /$ $\mathrm{Ca}$ channels) in vascular smooth muscle cells, promoting vasodilatation and preventing severe arterial contraction [62]. Furthermore, it has been proposed in an earlier report with monkey cerebral arteries that prejunctional muscarinic receptors of $\mathrm{M}_{2}$ subtype contribute to an inhibition by neurogenic $\mathrm{ACh}$ of nitroxidergic nerve function [63]. Therefore, in the present study, the ability of TGS to inhibit McN-A-343-evoked CA release supports the possible involvement of muscarinic receptor blockade in the increased release of NO.

In contrast, it has been reported that L-NAME inhibits ACh-induced CA secretion in bovine chromaffin cells [64], and that the NO donor SNP enhances nicotineinduced CA secretion in cultured bovine chromaffin cells [65]. These findings suggest that NO may facilitate cholinergic agonist-induced CA secretion. On the other hand, a few in vivo studies have suggested that $\mathrm{NO}$ does not play a role in regulation of adrenal CA secretion $[66,67]$.

Generally, the adrenal medulla has been employed as a model system to study numerous cellular functions involving not only noradrenergic nerve cells but also neurons. During neurogenic stimulation of the adrenal medulla, ACh is released from splanchnic nerve endings and activates cholinergic receptors on the chromaffin 
cell membrane [68]. This activation initiates a series of events known as stimulus-secretion coupling, culminating in the exocytotic release of CA and other components of the secretory vesicles into the extracellular space. Usually, two mechanisms are involved in the secretion of adrenal medullary hormones. Upon excitation of splanchnic nerves, ACh is released from the nerve terminals, and then activates nicotinic the CA secretion. Based on this fact, the present findings that TGS inhibited the CA secretory responses evoked by nicotinic receptor stimulation as well as by membrane depolarization in the adrenal medulla of SHRs seem to support the fact that, ginsenosides from Panax ginseng can decrease the blood pressure in both experimental animals and hypertensive patients $[9,10,12,13]$. These experimental results indicate that TGS-induced inhibitory activity of the CA secretory response evoked by stimulation of nicotinic receptors might contribute at least partly to its hypotensive mechanism. ACh, the physiological presynaptic transmitter at the adrenal medulla, which is released by depolarizing splanchnic nerve terminals and then activates nicotinic receptors, releases the $\mathrm{CA}$, and induces dopamine $\beta$-hydroxylase by calcium-dependent secretory process $[69,70]$. In terms of this fact, the present results suggest that TGS may inhibit CA secretion evoked by nicotinic stimulation from the splanchnic nerve ending through the blockade of nicotinic receptors. The CA release from the adrenal medulla in response to splanchnic nerve stimulation or nicotinic agonist is mediated by activation of nicotinic receptors located on the chromaffin cells. The exocytotic CA release from the chromaffin cells appears to be essentially similar to that occurring in noradrenergic axons [71,72]. ACh-evoked CA secretion has shown to be caused through stimulation of both nicotinic and muscarinic receptors in guinea-pig adrenal gland [73] as well as in the perfused rat adrenal glands [74]. In support of this idea, it has been found that the ginseng saponins, ginsenoside $\mathrm{Rg}_{2}$, a panaxatriol [6] as well as ginsenoside $\mathrm{Rg}_{3}$, a panaxadiol [8] block the nicotinic ACh receptors or the receptor-operated $\mathrm{Na}^{+}$channels (but not voltage-sensitive $\mathrm{Na}^{+}$and $\mathrm{Ca}^{2+}$ channels), inhibit $\mathrm{Na}^{+}$influx through the channels and consequently reduce both $\mathrm{Ca}^{2+}$ influx and the CA secretion in bovine adrenal chromaffin cells.

In this study, TGS inhibited the CA secretory responses evoked by ACh, high $\mathrm{K}^{+}$, DMPP, and McN-A-343. It suggests that TGS can produce the similar effect as in adrenal medulla of the normotensive rats [4] and also in bovine adrenal chromaffin cells $[6,8]$. In previous study, ginsenoside- $\mathrm{Rg}_{3}$ inhibited both ACh-induced $\mathrm{Ca}^{2+}$ and $\mathrm{Na}^{+}$influxes in a concentration-dependent manner similar to that observed with the ACh-evoked CA secretion [8]. However, it had no or only a slight effect on the CA secretion and $\mathrm{Ca}^{2+}$ influx induced by high $\mathrm{K}^{+}$concentration or veratridine, an activator of the voltage-sensitive $\mathrm{Ca}^{2+}$ or $\mathrm{Na}^{+}$channels $[5,6]$. These results strongly suggested that ginsenoside- $\operatorname{Rg}_{3}$ acts on the nicotinic $\mathrm{ACh}$ receptoroperated cation channels but not on the voltage-sensitive $\mathrm{Ca}^{2+}$ or $\mathrm{Na}^{+}$channels. Furthermore, the ginsenoside- $\mathrm{Rg}_{3}$ inhibition was not overcome by increasing the external $\mathrm{ACh}$ and $\mathrm{Ca}^{2+}$ concentrations [8], indicating that the inhibitory effect of ginsenoside- $\mathrm{Rg}_{3}$ is distinct from that of the competitive antagonists of the nicotinic ACh receptors, such as trimethaphan [75,76], and that of blockers of the L-type voltage-sensitive $\mathrm{Ca}^{2+}$ channels, which are competitive with external $\mathrm{Ca}^{2+}$ concentrations, such as diltiazem [77]. In fact, the mode of the ginsenoside- $\mathrm{Rg}_{3}$ antagonism was non-competitive with nicotine [8]. Anyway, these results seem to be quite different from those of the present study that TGS significantly inhibited the CA secretory responses evoked by cholinergic stimulation as well as an activator of the voltage-sensitive $\mathrm{Ca}^{2+}$ or $\mathrm{Na}^{+}$channels in the perfused model of SHR's adrenal medulla. The discrepancy is due to the experimental employment of different accounting methodology and different components between the present and previous studies.

In the present study, TGS also time-dependently depressed the CA secretory response evoked by Bay$\mathrm{K}-8644$, which is known to activate L-type voltagedependent $\mathrm{Ca}^{2+}$ channels $[38,78]$. This result indicates that TGS may inhibit $\mathrm{Ca}^{2+}$ influx to the adrenomedullary cells of SHRs. In support of this idea, in cultured bovine adrenal medullary cells, nicotinic (but not muscarinic) receptors mediate the $\mathrm{Ca}^{2+}$-dependent CA secretion $[79,80]$. It has also been known that the activation of nicotinic receptors stimulates the CA secretion by increasing $\mathrm{Ca}^{2+}$ entry through receptor-linked and/or voltagedependent $\mathrm{Ca}^{2+}$ channels in both perfused rat adrenal glands $[74,81]$ and isolated bovine adrenal chromaffin cells [82-84]. Wada and his coworkers [85] have found that the adrenomedullary chromaffin cells have 1) nicotinic receptor-associated ionic channels, responsible for carbachol-induced $\mathrm{Na}^{+}$influx, 2) voltage-dependent $\mathrm{Na}^{+}$ channels, responsible for veratridine-induced $\mathrm{Na}^{+}$influx and 3) voltage-dependent $\mathrm{Ca}^{2+}$ channels (VDCC), suggesting that the influx of $\mathrm{Na}^{+}$caused either by carbachol or by veratridine leads to activate voltage-dependent $\mathrm{Ca}^{2+}$ channels by altering membrane potentials, whereas high $\mathrm{K}^{+}$directly activates voltage-dependent $\mathrm{Ca}^{2+}$ channels without increasing $\mathrm{Na}^{+}$influx. In the present study, 
the finding that the CA secretory responses evoked by Bay-k-8644 as well as by high $\mathrm{K}^{+}$were depressed in the presence of TGS indicates that this inhibitory effect of TGS is exerted by the direct inhibition of calcium influx through VDCC into the adrenal chromaffin cells of SHRs. Furthermore, slight elevation in the extracellular potassium concentration increases both the frequency of spontaneous action potentials and the CA secretion [86], suggesting that the influx of calcium that occurs during action potentials is directly linked to the rate of secretion. These findings that TGS inhibited the CA secretion evoked by Bay-K-8644 as well as by high $\mathrm{K}^{+}$suggest that TGS can inhibit directly the VDCC. In the bovine chromaffin cells, stimulation of nicotinic, but not muscarinic $\mathrm{ACh}$ receptors is known to cause CA secretion by increasing $\mathrm{Ca}^{2+}$ influx largely through VDCC $[87,88]$. Therefore, it seems that these inhibitory effects of TGS on the CA secretion evoked by ACh, DMPP and veratridine may be mediated by inhibiting $\mathrm{Ca}^{2+}$ influx through voltage-dependent $\mathrm{Ca}^{2+}$ channels due to activation of nicotinic receptor-associated ionic channels, responsible for carbachol-induced $\mathrm{Na}^{+}$influx, as well as of voltagedependent $\mathrm{Na}^{+}$channels, responsible for veratridineinduced $\mathrm{Na}^{+}$influx.

The present study has also shown that TGS inhibits the CA secretion evoked by cyclopiazonic acid. Cyclopiazonic acid is known to be a highly selective inhibitor of $\mathrm{Ca}^{2+}$-ATPase in skeletal muscle sarcoplasmic reticulum $[40,41]$ and a valuable pharmacological tool for investigating intracellular $\mathrm{Ca}^{2+}$ mobilization and ionic currents regulated by intracellular $\mathrm{Ca}^{2+}$ [89]. Therefore, it is felt that the inhibitory effect of TGS on the CA secretion may also be associated with the mobilization of intracellular $\mathrm{Ca}^{2+}$ from the cytoplasmic calcium store. This indicates that the TGS can inhibit the release of $\mathrm{Ca}^{2+}$ from the intracellular pools induced by stimulation of muscarinic ACh receptors, which is weakly responsible for the CA secretion. It has been shown that $\mathrm{Ca}^{2+}$-uptake into intracellular storage sites susceptible to caffeine [90] is almost completely abolished by treatment with cyclopiazonic acid during the proceeding of $\mathrm{Ca}^{2+}$ load [89]. This is consistent with the findings obtained in skinned smooth muscle fibers of the longitudinal layer of the guinea-pig ileum, where $\mathrm{Ca}^{2+}$-uptake was also inhibited by cylopiazonic acid [91]. Suzuki and his coworkers [89] have shown that cyclopiazonic acid easily penetrates into the cytoplasm through the plasma membrane and reduces $\mathrm{Ca}^{2+}$-ATPase activity in sarcoplasmic/endoplasmic reticulum, resulting in an increase in the subsequent $\mathrm{Ca}^{2+}$ release from those storage sites. Moreover, in bo- vine adrenal chromaffin cells, stimulation of muscarinic ACh receptors is also proposed to cause activation of phosphoinositide metabolism, resulting in the formation of inositol 1,4,5-trisphosphate, which induces the mobilization of $\mathrm{Ca}^{2+}$ from the intracellular pools $[92,93]$. The present results suggest that TGS-induced depression of the CA secretion evoked by McN-A-343 and cyclopiazonic acid may be due to the inhibition of $\mathrm{Ca}^{2+}$ release from the intracellular pools induced by stimulation of muscarinic ACh receptors. However, in the present study, it is uncertain whether the inhibitory effect of TGS on $\mathrm{Ca}^{2+}$ movement from intracellular pools is due to its direct effect on the PI response or the indirect effects.

In conclusion, the results of the present study have strongly suggested that TGS inhibits the CA secretion by stimulation of cholinergic nicotinic receptors as well as by direct membrane depolarization in the isolated perfused adrenal glands of SHRs. It seems that this inhibitory effect of TGS is exerted by blocking influx of sodium and calcium through ionic channels into the adrenomedullary chromaffin cells of SHRs as well as by inhibiting the release of $\mathrm{Ca}^{2+}$ from the cytoplasmic calcium store at least partly via the increased NO production due to the activation of nitric oxide synthase. Based on these results, the ingestion of TGS may be helpful to prevent or alleviate the cardiovascular diseases, through inhibition of CA secretion from adrenomedullary chromaffin cells and consequent reduction of the CA level in the circulation.

\section{ACKNOWLEDGEMENTS}

This study was supported partly by the fund of Chosun University (2009).

\section{REFERENCES}

1. Lim D, Park K, Kim K, Lee K, Moon J, Kim Y. Influence of total ginseng saponin on secretion of catecholamines in the isolated adrenal gland of rabbits. Korean Biochem J 1987;20:230-238.

2. Lim DY, Park KB, Kim KH, Choi CH, Bae JW, Kim MW. Studies on secretion of catecholamines evoked by panaxadiol in the isolated rabbit adrenal gland. Korean J Pharmacol 1988;24:31-42.

3. Lim DY, Choi CH, Kim CD, Kim KH, Kim SB, Lee BJ, Chung MH. Influnce of Panaxatriol-type saponin on secretion of catecholamines from isolated perfused rabbit adrenal gland. Arch Pharm Res 1989;12:166-175.

4. Hong SP, Chi H, Cho SH, Lee YK, Woo SC, Kim IS, Oh 
SH, Yang WH, Lim DY. Influence of total ginseng saponin on nicotinic stimulation-induced catecholamine secretion from the perfused rat adrenal gland. Korean J Hypert 1999;5:159-168.

5. Kudo K. Effects of red ginseng fractions on catecholamine secretion from bovine adrenal medullary cells. J Med Pharm Soc Wakan-Yaku 1992;9:236-239.

6. Tachikawa E, Kudo K, Kashimoto T, Takahashi E. Ginseng saponins reduce acetylcholine-evoked $\mathrm{Na}+$ influx and catecholamine secretion in bovine adrenal chromaffin cells. J Pharmacol Exp Ther 1995;273:629-636.

7. Kudo K, Tachikawa E, Kashimoto T, Takahashi E. Properties of ginseng saponin inhibition of catecholamine secretion in bovine adrenal chromaffin cells. Eur J Pharmacol 1998;341:139-144.

8. Tachikawa E, Kudo K, Nunokawa M, Kashimoto T, Takahashi E, Kitagawa S. Characterization of ginseng saponin ginsenoside- $\operatorname{Rg}(3)$ inhibition of catecholamine secretion in bovine adrenal chromaffin cells. Biochem Pharmacol 2001;62:943-951.

9. Kim ND, Kang SY, Schini VB. Ginsenosides evoke endothelium-dependent vascular relaxation in rat aorta. Gen Pharmacol 1994;25:1071-1077.

10. Han KH, Choe SC, Kim HS, Sohn DW, Nam KY, Oh BH, Lee MM, Park YB, Choi YS, Seo JD et al. Effect of red ginseng on blood pressure in patients with essential hypertension and white coat hypertension. Am J Chin Med 1998;26:199-209.

11. Jeon BH, Kim CS, Kim HS, Park JB, Nam KY, Chang SJ. Effect of Korean red ginseng on blood pressure and nitric oxide production. Acta Pharmacol Sin 2000;21:10951100.

12. Jeon BH, Kim CS, Park KS, Lee JW, Park JB, Kim KJ, Kim SH, Chang SJ, Nam KY. Effect of Korea red ginseng on the blood pressure in conscious hypertensive rats.Gen Pharmacol 2000;35:135-141.

13. Sung J, Han KH, Zo JH, Park HJ, Kim CH, Oh BH. Effects of red ginseng upon vascular endothelial function in patients with essential hypertension. Am J Chin Med 2000;28:205-216.

14. Siegel RK. Ginseng abuse syndrome. Problems with the panacea. JAMA 1979;241:1614-1615.

15. Baldwin CA, Anderson LA, Phillipson JD. What pharmacists should know about ginseng. Pharm J 1986;237:583586.

16. Miller LG. Herbal medicinals: selected clinical considerations focusing on known or potential drug-herb interactions. Arch Intern Med 1998;158:2200-2211.

17. Klepser TB, Klepser ME. Unsafe and potentially safe herbal therapies. Am J Health Syst Pharm 1999;56:125-
138.

18. Lim DY, Park KB, Kim KH, Moon JK, Lee KS, Kim YK, Chung YH, Hong SP. Influnce of total ginseng saponin on the blood pressure of the rat. Korean Circ J 1987;17:491499.

19. Sohn ES, Park SC, Huh BY, Lee CK, Rhim HK, Ham JS, Young CM, Han CS, Park CW, Kim HJ. An animal experiental study on the effect of ginseng on blood pressure and plasma renin activity in spontaneously hypertensive rat. J Korean Med Assoc 1979;22:731-745.

20. Sohn ES, Park SC, Huh BY, Lee DH, Rhim HK, Young CM, Han CS, Song BS, Kim SJ, Park CW, et al. An animal experimental study of the effect of Korean ginseng on body weight and blood pressure in spontaneously hypertensive rat with oral administration. J Korea Med Assoc 1980;23:37-48.

21. Seok SE, Park CH, Nam SH, Choi HS, Lee JI, Lee DH, Huh BY, Soh ES. An experimental study on the antihypertensive effect of Korea ginseng to spontanously hypertensive rats (SHR) in labile stage of hypertension. J Korean Med Assoc 1981;24:509-515.

22. Sokabe H, Kishi K, Watanabe TX. Effects of Korean red ginseng powder (GP) administered orally, on blood pressure in hypertensive rats. In: Korea Ginseng Research Institute. Proceeding of the 4th International Ginseng Symposium; Seoul, Korea, 1984. p.127-132.

23. Stavro PM, Woo M, Leiter LA, Heim TF, Sievenpiper JL, Vuksan V. Long-term intake of North American ginseng has no effect on 24-hour blood pressure and renal function. Hypertension 2006;47:791-796.

24. Kim ND, Kim EM, Kang KW, Cho MK, Choi SY, Kim SG. Ginsenoside $\mathrm{Rg}_{3}$ inhibits phenylephrine-induced vascular contraction through induction of nitric oxide synthase. Br J Pharmacol 2003;140:661-670.

25. Han K, Shin IC, Choi KJ, Yun YP, Hong JT, Oh KW. Korea red ginseng water extract increases nitric oxide concentrations in exhaled breath. Nitric Oxide 2005;12:159162.

26. Kim ND, Kang SY, Park JH, Schini-Kerth VB. Ginsenoside $\mathrm{Rg}_{3}$ mediates endothelium-dependent relaxation in response to ginsenosides in rat aorta: role of $\mathrm{K}^{+}$channels. Eur J Pharmacol 1999;367:41-49.

27. Kang SY, Schini-Kerth VB, Kim ND. Ginsenosides of the protopanaxatriol group cause endothelium-dependent relaxation in the rat aorta. Life Sci 1995;56:1577-1586.

28. Hien TT, Kim ND, Pokharel YR, Oh SJ, Lee MY, Kang $\mathrm{KW}$. Ginsenoside $\mathrm{Rg}_{3}$ increases nitric oxide production via increases in phosphorylation and expression of endothelial nitric oxide synthase: essential roles of estrogen receptor-dependent PI3-kinase and AMP-activated pro- 
tein kinase. Toxicol Appl Pharmacol 2010; Epub ahead of print.

29. Leung KW, Cheng YK, Mak NK, Chan KK, Fan TP, Wong RN. Signaling pathway of ginsenoside- $\operatorname{Rg}_{1}$ leading to nitric oxide production in endothelial cells. FEBS Lett 2006;580:3211-3216.

30. Han SW, Kim H. Ginsenosides stimulate endogenous production of nitric oxide in rat kidney. Int J Biochem Cell Biol 1996;28:573-580.

31. Chai H, Zhou W, Lin P, Lumsden A, Yao Q, Chen C. Ginsenosides block HIV protease inhibitor ritonavir-induced vascular dysfunction of porcine coronary arteries. Am J Physiol Heart Circ Physiol 2005;288:H2965-H2971.

32. Wakade AR. Studies on secretion of catecholamines evoked by acetylcholine or transmural stimulation of the rat adrenal gland. J Physiol 1981;313:463-480.

33. Anton AH, Sayre DF. A study of the factors affecting the aluminum oxide-trihydroxyindole procedure for the analysis of catecholamines. J Pharmacol Exp Ther 1962;138:360-375.

34. McVeigh GE, Hamilton P, Wilson M, Hanratty CG, Leahey WJ, Devine AB, Morgan DG, Dixon LJ, McGrath LT. Platelet nitric oxide and superoxide release during the development of nitrate tolerance: effect of supplemental ascorbate. Circulation 2002;106:208-213.

35. Tallarida RJ, Murray RB. Manual of pharmacologic calculations with computer programs. 2nd ed. New York: Speringer-Verlag, 1987.

36. Tachikawa E, Kudo K, Hasegawa H, Kashimoto T, Sasaki $\mathrm{K}$, Miyazaki M, Taira $\mathrm{H}$, Lindstrom JM. In vitro inhibition of adrenal catecholamine secretion by steroidal metabolites of ginseng saponins. Biochem Pharmacol 2003;66:2213-2221.

37. Hammer R, Giachetti A. Muscarinic receptor subtypes: M1 and M2 biochemical and functional characterization. Life Sci 1982;31:2991-2998.

38. Garcia AG, Sala F, Reig JA, Viniegra S, Frias J, Fonteriz R, Gandia L. Dihydropyridine BAY-K-8644 activates chromaffin cell calcium channels. Nature 1984;309:69-71.

39. Lim DY, Kim CD, Ahn GW. Influence of TMB-8 on secretion of catecholamines from the perfused rat adrenal glands. Arch Pharm Res 1992;15:115-125.

40. Goeger DE, Riley RT. Interaction of cyclopiazonic acid with rat skeletal muscle sarcoplasmic reticulum vesicles. Effect on $\mathrm{Ca}^{2+}$ binding and $\mathrm{Ca}^{2+}$ permeability. Biochem Pharmacol 1989;38:3995-4003.

41. Seidler NW, Jona I, Vegh M, Martonosi A. Cyclopiazonic acid is a specific inhibitor of the $\mathrm{Ca}^{2+}$-ATPase of sarcoplasmic reticulum. J Biol Chem 1989;264:17816-17823.

42. Wada Y, Satoh K, Taira N. Cardiovascular profile of Bay
K 8644, a presumed calcium channel activator, in the dog. Naunyn Schmiedebergs Arch Pharmacol 1985;328:382387.

43. Gillis CN. Panax ginseng pharmacology: a nitric oxide link? Biochem Pharmacol 1997;54:1-8.

44. Chen X, Gillis CN, Moalli R. Vascular effects of ginsenosides in vitro. Br J Pharmacol 1984;82:485-491.

45. Toda N, Ayajiki K, Fujioka H, Okamura T. Ginsenoside potentiates NO-mediated neurogenic vasodilatation of monkey cerebral arteries. J Ethnopharmacol 2001;76:109113.

46. Lim JH, Wen TC, Matsuda S, Tanaka J, Maeda N, Peng H, Aburaya J, Ishihara K, Sakanaka M. Protection of ischemic hippocampal neurons by ginsenoside Rb1, a main ingredient of ginseng root. Neurosci Res 1997;28:191200.

47. Kim DH, Jung JS, Suh HW, Huh SO, Min SK, Son BK, Park JH, Kim ND, Kim YH, Song DK. Inhibition of stress-induced plasma corticosterone levels by ginsenosides in mice: involvement of nitric oxide. Neuroreport 1998;9:2261-2264.

48. Chen X, Lee TJ. Ginsenosides-induced nitric oxidemediated relaxation of the rabbit corpus cavernosum. Br J Pharmacol 1995;115:15-18.

49. Toda N, Tanaka T, Ayajiki K, Okamura T. Cerebral vasodilatation induced by stimulation of the pterygopalatine ganglion and greater petrosal nerve in anesthetized monkeys. Neuroscience 2000;96:393-398.

50. Ayajiki K, Hayashida H, Okamura T, Toda N. Pelvic nerve stimulation-induced pressor responses in corpus cavernosum of anesthetized dogs. Am J Physiol 1997;273(5 Pt 2):H2141-H2145.

51. Toda N, Okamura T. Regulation by nitroxidergic nerve of arterial tone. News Physiol Sci 1992;7:148-152.

52. Toda N, Okamura T. Nitroxidergic nerve: regulation of vascular tone and blood flow in the brain. J Hypertens 1996; 14:423-434.

53. Burnett AL, Lowenstein CJ, Bredt DS, Chang TS, Snyder SH. Nitric oxide: a physiologic mediator of penile erection. Science 1992;257:401-403.

54. Palmer RM, Ashton DS, Moncada S. Vascular endothelial cells synthesize nitric oxide from L-arginine. Nature 1988;333:664-666.

55. Sakuma I, Stuehr DJ, Gross SS, Nathan C, Levi R. Identification of arginine as a precursor of endothelium-derived relaxing factor. Proc Natl Acad Sci U S A 1988;85:86648667.

56. Marley PD, McLeod J, Anderson C, Thomson KA. Nerves containing nitric oxide synthase and their possible function in the control of catecholamine secretion in the 
bovine adrenal medulla. J Auton Nerv Syst 1995;54:184194.

57. Oset-Gasque MJ, Parramon M, Hortelano S, Bosca L, Gonzalez MP. Nitric oxide implication in the control of neurosecretion by chromaffin cells. J Neurochem 1994;63:1693-1700.

58. Palacios M, Knowles RG, Palmer RM, Moncada S. Nitric oxide from L-arginine stimulates the soluble guanylate cyclase in adrenal glands. Biochem Biophys Res Commun 1989;165:802-809.

59. Schwarz PM, Rodriguez-Pascual F, Koesling D, Torres M, Forstermann U. Functional coupling of nitric oxide synthase and soluble guanylyl cyclase in controlling catecholamine secretion from bovine chromaffin cells. Neuroscience 1998;82:255-265.

60. Torres M, Ceballos G, Rubio R. Possible role of nitric oxide in catecholamine secretion by chromaffin cells in the presence and absence of cultured endothelial cells. J Neurochem 1994;63:988-996.

61. Rodriguez-Pascual F, Miras-Portugal MT, Torres M. Effect of cyclic GMP-increasing agents nitric oxide and Ctype natriuretic peptide on bovine chromaffin cell function: inhibitory role mediated by cyclic GMP-dependent protein kinase. Mol Pharmacol 1996;49:1058-1070.

62. Nakaya Y, Mawatari K, Takahashi A, Harada N, Hata A, Yasui S. The phytoestrogen ginsensoside Re activates potassium channels of vascular smooth muscle cells through PI3K/Akt and nitric oxide pathways. J Med Invest 2007;54:381-384.

63. Toda N, Ayajiki K, Okamura T. Inhibition of nitroxidergic nerve function by neurogenic acetylcholine in monkey cerebral arteries. J Physiol 1997;498(Pt 2):453-461.

64. Uchiyama Y, Morita K, Kitayama S, Suemitsu T, Minami N, Miyasako T, Dohi T. Possible involvement of nitric oxide in acetylcholine-induced increase of intracellular $\mathrm{Ca}^{2+}$ concentration and catecholamine release in bovine adrenal chromaffin cells. Jpn J Pharmacol 1994;65:73-77.

65. O'Sullivan AJ, Burgoyne RD. Cyclic GMP regulates nicotine-induced secretion from cultured bovine adrenal chromaffin cells: effects of 8-bromo-cyclic GMP, atrial natriuretic peptide, and nitroprusside (nitric oxide). J Neurochem 1990;54:1805-1808.

66. Breslow MJ, Tobin JR, Bredt DS, Ferris CD, Snyder SH, Traystman RJ. Role of nitric oxide in adrenal medullary vasodilation during catecholamine secretion. Eur J Pharmacol 1992;210:105-106.

67. Breslow MJ, Tobin JR, Bredt DS, Ferris CD, Snyder SH, Traystman RJ. Nitric oxide as a regulator of adrenal blood flow. Am J Physiol 1993;264(2 Pt 2):H464-H469.

68. Viveros $\mathrm{OH}$. Mechanism of secretion of catecholaminies from adrenal medulla. In: Greep RO. Handbook of physiology endocrinology. Washington DC: American Physiological Society, 1975. p.389-426.

69. Dixon WR, Garcia AG, Kirpekar SM. Release of catecholamines and dopamine beta-hydroxylase from the perfused adrenal gland of the cat. J Physiol 1975;244:805824.

70. Viveros OH, Arqueros L, Kirshner N. Release of catecholamines and dopamine beta-hydroxylase from the adrenal medulla. Life Sci 1968;7:609-618.

71. Douglas WW. Stimulus-secretion coupling: the concept and clues from chromaffin and other cells. Br J Pharmacol 1968;34:451-474.

72. Sorimachi M, Yoshida K. Exocytotic release of catecholamines and dopamine-beta-hydroxylase from the perfused adrenal gland of the rabbit and cat. Br J Pharmacol 1979;65:117-125.

73. Nakazato Y, Ohga A, Oleshansky M, Tomita U, Yamada Y. Voltage-independent catecholamine release mediated by the activation of muscarinic receptors in guinea-pig adrenal glands. Br J Pharmacol 1988;93:101-109.

74. Lim DY, Hwang DH. Studies on secretion of catecholamines evoked by DMPP and McN-A-343 in the rat adrenal gland. Korean J Pharmacol 1991;27:53-67.

75. Rang HP, Colquhoun D, Rang HP. The action of ganglionic blocking drugs on the synaptic responses of rat submandibular ganglion cells. Br J Pharmacol 1982;75:151168.

76. Weaver WR, Wolf KM, Chiappinelli VA. Functional heterogeneity of nicotinic receptors in the avian lateral spiriform nucleus detected with trimethaphan. Mol Pharmacol 1994;46:993-1001.

77. Wada A, Yanagihara N, Izumi F, Sakurai S, Kobayashi H. Trifluoperazine inhibits ${ }^{45} \mathrm{Ca}^{2+}$ uptake and catecholamine secretion and synthesis in adrenal medullary cells. J Neurochem 1983;40:481-486.

78. Schramm M, Thomas G, Towart R, Franckowiak G. Novel dihydropyridines with positive inotropic action through activation of $\mathrm{Ca}^{2+}$ channels. Nature 1983;303:535-537.

79. Fisher SK, Holz RW, Agranoff BW. Muscarinic receptors in chromaffin cell cultures mediate enhanced phospholipid labeling but not catecholamine secretion. J Neurochem 1981;37:491-497.

80. Yanagihara N, Isosaki M, Ohuchi T, Oka M. Muscarinic receptor-mediated increase in cyclic GMP level in isolated bovine adrenal medullary cells. FEBS Lett 1979;105:296298.

81. Wakade AR, Wakade TD. Contribution of nicotinic and muscarinic receptors in the secretion of catecholamines evoked by endogenous and exogenous acetylcholine. 
Neuroscience 1983;10:973-978.

82. Kilpatrick DL, Slepetis R, Kirshner N. Ion channels and membrane potential in stimulus-secretion coupling in adrenal medulla cells. J Neurochem 1981;36:1245-1255.

83. Kilpatrick DL, Slepetis RJ, Corcoran JJ, Kirshner N. Calcium uptake and catecholamine secretion by cultured bovine adrenal medulla cells. J Neurochem 1982;38:427435.

84. Knight DE, Kesteven NT. Evoked transient intracellular free $\mathrm{Ca} 2+$ changes and secretion in isolated bovine adrenal medullary cells. Proc R Soc Lond B Biol Sci 1983;218:177-199.

85. Wada A, Takara H, Izumi F, Kobayashi H, Yanagihara N. Influx of ${ }^{22} \mathrm{Na}$ through acetylcholine receptor-associated $\mathrm{Na}$ channels: relationship between ${ }^{22} \mathrm{Na}$ influx, ${ }^{45} \mathrm{Ca}$ influx and secretion of catecholamines in cultured bovine adrenal medulla cells. Neuroscience 1985;15:283-292.

86. Kidokoro Y, Ritchie AK. Chromaffin cell action potentials and their possible role in adrenaline secretion from rat adrenal medulla. J Physiol 1980;307:199-216.

87. Burgoyne RD. Mechanisms of secretion from adrenal chromaffin cells. Biochim Biophys Acta 1984;779:201216.

88. Oka M, Isosaki M, Yanagihara N. Isolated bovine adrenal medullary cells: studies on regulation of catecholamine synthesis and release. In: Usdin E, Kopin IJ, Barchas J, eds. Catecholamines: basic and clinical frontiers. Oxford: Pergamon Press, 1979. p.70-72.

89. Suzuki M, Muraki K, Imaizumi Y, Watanabe M. Cyclopiazonic acid, an inhibitor of the sarcoplasmic reticulum $\mathrm{Ca}(2+)$-pump, reduces $\mathrm{Ca}(2+)$-dependent $\mathrm{K}^{+}$currents in guinea-pig smooth muscle cells. Br J Pharmacol 1992;107:134-140.

90. Iino M. Calcium-induced calcium release mechanism in guinea pig taenia caeci. J Gen Physiol 1989;94:363-383.

91. Uyama Y, Imaizumi Y, Watanabe M. Effects of cyclopiazonic acid, a novel $\mathrm{Ca}(2+)$-ATPase inhibitor, on contractile responses in skinned ileal smooth muscle. Br J Pharmacol 1992;106:208-214.

92. Cheek TR, O'Sullivan AJ, Moreton RB, Berridge MJ, Burgoyne RD. Spatial localization of the stimulus-induced rise in cytosolic $\mathrm{Ca}^{2+}$ in bovine adrenal chromaffin cells. Distinct nicotinic and muscarinic patterns. FEBS Lett 1989;247:429-434.

93. Challis RA, Jones JA, Owen PJ, Boarder MR. Changes in inositol 1,4,5-trisphosphate and inositol 1,3,4,5- tetrakisphosphate mass accumulations in cultured adrenal chromaffin cells in response to bradykinin and histamine. J Neurochem 1991;56:1083-1086. 